\title{
Challenges to Democracy in the Middle East
}

William Harris, Amatzia Baram, Ahmad Ashraf,

Heath Lowry, and Yesim Arat.

Princeton, NJ: Markus Weiner Publishers, 1997. 132 pages.

Many scholars have attempted to tackle the question of why democracy has seemingly failed to take root in the Islamic milieu, in general, and the predominantly Arab Middle East, in particular, while the rest of the world has witnessed the fall of "pax-authoritaria" especially in the wake of the democratic revolution triggered by the failure of communism. Some view this resistance to the Third Wave, as being rooted in the Islamic cultural dynamics of the region, whereas others will ascribe it to the level of political development (or the lack thereof). An anthology of essays, Challenges to Democracy in the Middle East furnishes the reader with five historical case studies that seek to explain the arrested socio politico-economic development of Syria, Lebanon, Iraq, Iran, and Turkey, and the resulting undemocratic political culture that dominates the overall political landscape of the Middle East.

The first composition in this omnibus is "The Crisis of Democracy in Twentieth Century Syria and Lebanon," authored by Bill Harris, senior lec- 
turer of political studies at the University of Otago in Dunedin, New Zealand. Harris compares and contrasts the political development of Syria and Lebanon during the French mandate period and under the various regimes since then. He examines how the two competing forms of nationalism, i.e., Lebanonism and Arabism, along with sectarianism, are the main factors that have contributed to the consolidation of one-party rule in Syria, and the 16-year internecine conflict in Lebanon. After a brief overview of the early history of both countries, the author spends a great deal of time discussing the relatively more recent political developments: Syria from 1970 onwards, and Lebanon from 1975 to the 1990s. Harris expresses deep pessimism regarding the future of democratic politics in both countries, which in his opinion is largely due to the deep sectarian cleavages in both states.

The next treatise is "Re-Inventing Nationalism in Bathi Iraq 19681994: SupraTerritorial Identities and What Lies Below," by Amatzia Baram, professor of Middle East History at the University of Haifa. Baram surveys the Ba'th's second stint in power (1968-present) in Iraq. Baram's opinion is that a shift has occurred in Bathist ideology from an integrative Pan-Arab program to an Iraqi-centered Arab nationalism. She attributes this to Saddam's romance with the past, on the one hand, which is the reason for the incorporation of themes from both the ancient Mesopotamian civilization and the medieval Abbasid caliphal era, and, on the other hand, to Islam and tribalism, that inform the pragmatic concerns of the Ba thist ideological configuration.

Baram pays particular attention to the incorporation of Islamic symbols in the Bathist propaganda, arguing that this has served many purposes including the offsetting of the effects of the Islamic revolution in Iran, disproving the accusation of promoting atheism, and dealing with the ShiaSunni dialectic. As for tribalism, it assisted greatly in the regime's efforts to quell the 1991 uprising in the south. Baram concludes that despite the ideological acrobatics, Iraqi-led Arab nationalism is still at the heart of Saddam's resilience in being able to rule Iraq. While Baram does go into quite a few details to explain the dynamics of Saddam Hussein's authoritarian regime, she does not demonstrate exactly how the shift from Pan-Arabism to Iraqi nationalism is responsible for the arrested development of democracy in Iraq.

Ahmad Ashraf's paper, "The Appeal of Conspiracy Theories to Persians," deals with the issue of conspiracy theories and their popularity among Persians throughout history. Ashraf, who has taught sociology and Persian social history at the University of Pennsylvania, Columbia, Prince- 
ton, and Tehran University, while acknowledging that conspiracy theories are a universal phenomenon, nevertheless believes that they are more popular among Middle Easterners, and disproportionately more so among Persians. In his viewpoint, this is due to a number of factors, which are unique to Persian history (both pre and post-Islamic): frequent foreign interference in the 19th and 20th centuries; the autocratic nature of Persian politics; tight government control on the media; conspiracy theories as efficient collective defense mechanisms; and the Shiite conception of satanic forces. These are the prime dynamics behind the Persian proclivity toward conspiracy theories. Ashraf classifies Persian conspiracy theories into two general categories, particularistic (theories in which Persians charge Britain, Russia and the United States with plotting against Iran) and universalistic (theories involving Hellenic westernism, European Crusaders, Freemasonry, Zionism, Baha'is, and even Shi ite ulama). Ashraf concludes by highlighting more recent attempts to liberate the Persian populace from the intoxicating influence of conspiracy theories.

Heath Lowry, professor of Ottoman and Modern Turkish Studies at Princeton University, in his paper, "Challenges to the Turkish Democracy in the Decade of the Nineties," seeks to highlight certain taboos, beginning in the late 70 s/early 80 s, which, in his opinion, are impeding Turkey's potential of developing into a mature free-market democracy. Lowry discusses how the Turko-centric view of history, obsession with an almost atheistic form of secularism, ethnocentric-based Turkish nationalism, shunning of any talk of Pan-Turanism, state monopoly over information, and the overarching figurehead of Ataturk (Atatürkcülük, "the Atatürk legacy," the ultimate taboo) have all frustrated the process of democratization. Lowry further explains how, over time, Turks have been able to break with the recent past, and have begun to question that which was hitherto considered inviolable. He warns that with the withering away of these taboos, Turkey is in need of alternatives that can replace Kemalism, which hitherto was able to act as the binding force keeping the republic together. His prescription to this seemingly turbulent phase in the history of Turkish republicanism is a revision of its path to the future, based on a realization that Turkey is a multiethnic state suffering from a mounting economic disparity in an era marked by Islamic resurgence.

"A Feminist Mirror in Turkey: Portraits of Two Activists in the 1980s" by Yesim Arat, professor of political science at Bogaziçi University in Istanbul, Turkey, is the last essay in this collection. Her work is a comparative analysis of two competing strands of feminism in Turkey during the 
1980s. According to Arat, on one end of the Turkish feminist spectrum are the Kemalist (Egalitarian) feminists, while on the other end, there are the new generation feminists. Arat's article is mostly based on interviews with two women, each representing one of the two different schools of feminist thought. In an effort to maintain their anonymity, she identifies these two women by their initials. The egalitarian faction is represented by A.K., a physician by profession. Her radical counterpart is a political scientist whom Arat chooses to refer to as P.T. The locus of Turkish feminism, according to Arat, is situated somewhere in the nexus of change, in the views of both these generations. For Arat, both groups were locked in a collaborationistconfrontationalist type of hybrid relationship during the 1980s. Arat accounts for the difference in the two as a normal variation that all ideas undergo over a period of time. She also compares Turkish feminist thinking with that in the West and sees a commonality where a new generation of feminists seeks equality as well as difference. Conversely, Arat also notices that, unlike their western counterparts, the new brand of feminists in Turkey have constructed their ideology in opposition to the legacy of their founding father. In spite of this minor difference, Arat sees both schools of Turkish feminism as eventually being influenced by western feminists.

Overall, Challenges to Democracy in the Middle East is a collection of incongruent essays that do not appear to be relevant to Islamic thought, per se. Apparently, the publishers were trying to capture a wide circulation by incorporating essays from a host of disciplines, i.e., political science, history, sociology, and psychology. In terms of form, the book conspicuously does not have any editor(s), and is also devoid of a section that would provide the reader with some background information about its authors. The brief biographical information pertaining to the contributors of this book was made possible due to an Internet search conducted by this reviewer. Also missing is a badly needed concluding section, which would have, at the bare minimum, tied the five essays together, such that they might converge on the overall theme of the book. Another structural deficiency in this book is the absence of an index.

On the substantive side, only the first and fourth essays directly address the topic of the book, whereas the other three explore issues that are at best tangential to the theme. While Harris, Baram and Lowry have tried to remain focused on the issue of democracy, the essays by Ashraf and Arat have very little (if at all) to do with democracy. As for offering explanations to the regions' peculiar resistance to democratization, the essays by Harris and Baram underscore reasons that are political in nature whereas Lowry, 
Ashraf, and Arat place emphasis on cultural factors. Notwithstanding all these shortcomings, with organization, each essay on its own is reasonably informative of the individual topics that it seeks to accentuate.

Kamran Asghar Bokhari Graduate Research Assistant Center for Middle Eastern Studies University of Texas at Austin Austin, Texas 